\title{
Corrigendum: A Response to Scientific and Societal Needs for Marine Biological Observations
}

\section{OPEN ACCESS}

Approved by:

Frontiers Editorial Office

Frontiers Media SA, Switzerland

${ }^{*}$ Correspondence: Nicholas J. Bax nic.bax@csiro.au

Patricia Miloslavich pmilos@usb.ve

Specialty section

This article was submitted to

Ocean Observation,

a section of the journal

Frontiers in Marine Science

Received: 30 September 2019 Accepted: 01 October 2019

Published: 18 October 2019

Citation:

Bax NJ, Miloslavich P, Muller-Karger FE, Allain $V$, Appeltans W, Batten SD, Benedetti-Cecchi L, Buttigieg PL,

Chiba S, Costa DP, Duffy JE,

Dunn DC, Johnson CR, Kudela RM, Obura D, Rebelo L-M, Shin Y-J,

Simmons SE and Tyack PL (2019)

Corrigendum: A Response to

Scientific and Societal Needs for

Marine Biological Observations.

Front. Mar. Sci. 6:643.

doi: 10.3389/fmars.2019.00643

\begin{abstract}
Nicholas J. Bax ${ }^{1,2 *}$, Patricia Miloslavich ${ }^{1,2,3 *}$, Frank Edgar Muller-Karger ${ }^{4}$, Valerie Allain ${ }^{5}$, Ward Appeltans ${ }^{6}$, Sonia Dawn Batten ${ }^{7}$, Lisandro Benedetti-Cecchi ${ }^{8}$, Pier Luigi Buttigieg ${ }^{9}$, Sanae Chiba ${ }^{10,11}$, Daniel Paul Costa ${ }^{12}$, J. Emmett Duffy ${ }^{13}$, Daniel C. Dunn ${ }^{14}$, Craig Richard Johnson ${ }^{2}$, Raphael M. Kudela ${ }^{15}$, David Obura ${ }^{16,17}$, Lisa-Maria Rebelo ${ }^{18}$, Yunne-Jai Shin ${ }^{19,20}$, Samantha Elisabeth Simmons ${ }^{21}$ and Peter Lloyd Tyack ${ }^{22}$

${ }^{1}$ Oceans and Atmosphere, CSIRO, Hobart, TAS, Australia, ${ }^{2}$ Institute for Marine and Antarctic Studies, University of Tasmania, Hobart, TAS, Australia, ${ }^{3}$ Departamento de Estudios Ambientales, Universidad Simón Bolívar, Caracas, Venezuela, ${ }^{4}$ Institute for Marine Remote Sensing, College of Marine Science, University of South Florida, St. Petersburg, St. Petersburg, FL, United States, ${ }^{5}$ Secretariat of the Pacific Community, Noumea, France, ${ }^{6}$ Intergovernmental Oceanographic Commission of UNESCO, IOC Project Office for IODE, Ostend, Belgium, ${ }^{7}$ The CPR Survey-MBA, Nanaimo, BC, Canada, ${ }^{8}$ Department of Biology, University of Pisa, CoNISMa, Pisa, Italy, ${ }^{9} \mathrm{Helmholtz} \mathrm{Zentrum} \mathrm{für} \mathrm{Polar-} \mathrm{und} \mathrm{Meeresforschung,} \mathrm{Alfred} \mathrm{Wegener}$ Institut, Bremerhaven, Germany, ${ }^{10}$ JAMSTEC, Yokohama, Japan, ${ }^{11}$ UNEP-WCMC, Cambridge, United Kingdom,

${ }^{12}$ Department of Ecology and Evolutionary Biology, University of California, Santa Cruz, Santa Cruz, CA, United States, ${ }^{13}$ Smithsonian, Washington, DC, United States, ${ }^{14}$ Nicholas School of the Environment, Duke University, Durham, NC, United States, ${ }^{15}$ Ocean Sciences Department, University of California, Santa Cruz, Santa Cruz, CA, United States, ${ }^{16}$ Coastal Oceans Research and Development in the Indian Ocean (CORDIO East Africa), Mombasa, Kenya, ${ }^{17} \mathrm{Global}$ Change Institute, The University of Queensland, Brisbane, QLD, Australia, ${ }^{18}$ International Water Management Institute, Regional Office for SE Asia and the Mekong, Vientiane, Laos, ${ }^{19}$ MARBEC (IRD, Univ. Montpellier, IFREMER, CNRS), Montpellier, France,

${ }^{20}$ Department of Biological Sciences, Ma-Re Institute, University of Cape Town, Cape Town, South Africa, ${ }^{21}$ Marine Mammal Commission, Bethesda, MD, United States, ${ }^{22}$ Marine Biological Association, Nanaimo, BC, Canada
\end{abstract}

Keywords: GOOS, capacity development, EOV, ocean observing, essential ocean variable, UN Decade, Sustainable Development Goals

\section{A Corrigendum on}

A Response to Scientific and Societal Needs for Marine Biological Observations by Bax, N. J., Miloslavich, P., Muller-Karger, F. E., Allain, V., Appeltans, W., Batten, S. D., et al. (2019). Front. Mar. Sci. 6:395. doi: 10.3389/fmars.2019.00395

In the published article, there was an error regarding the affiliations for "Patricia Miloslavich." As well as having affiliations "2" and "3," they should also have "Oceans and Atmosphere, CSIRO, Hobart, TAS, Australia.”

The authors apologize for this error and state that this does not change the scientific conclusions of the article in any way. The original article has been updated.

Copyright (c) 2019 Bax, Miloslavich, Muller-Karger, Allain, Appeltans, Batten, Benedetti-Cecchi, Buttigieg, Chiba, Costa, Duffy, Dunn, Johnson, Kudela, Obura, Rebelo, Shin, Simmons and Tyack. This is an open-access article distributed under the terms of the Creative Commons Attribution License (CC BY). The use, distribution or reproduction in other forums is permitted, provided the original author(s) and the copyright owner(s) are credited and that the original publication in this journal is cited, in accordance with accepted academic practice. No use, distribution or reproduction is permitted which does not comply with these terms. 